\title{
Analysis of changes in resources and outputs of companies and partnerships in Hungarian agriculture
}

\author{
Harangi-Rákos Mónika \\ University of Debrecen Centre for Agricultural and Applied Economic Sciences \\ Institute of Economic Theory \\ 4032 Debrecen, Böszörményi 138. \\ rakosm@agr.unideb.hu
}

Keywords: agricultural companies and partnerships, agricultural co-operatives, employment, inputs, outputs

\section{SUMMARY}

\begin{abstract}
The aim of the study was to examine the achievement of Hungarian agricultural companies and partnerships, particularly agricultural co-operatives based on the aggregated database of National Tax and Customs Administration (NAV) ${ }^{l}$. From the methodological aspect, descriptive statistical methods and time series analysis were used. One of the most important conclusions is that the socio-economic weight of the agricultural co-operatives was strongly decreased in the period after the EU accession. The other important statement is that apart from the general examination of economic actors on aggregated level the comparative analysis of the single organizations forms would be needed. In the case of co-operatives, separated examination of the former type producer co-operatives and the so-called new type ones (e.g. marketing co-operatives etc.) would be necessary.
\end{abstract}

\section{Introduction}

The aim of my study is to present resources (inputs) and outputs of agricultural companies and partnerships, particularly co-operatives, concerning the period 2002-2007. My study is unique because in the publishing of the last decade, one cannot find any nationwide analysis of the socioeconomic role of agricultural co-operatives based on financial data. Studies published by the Hungarian Central Statistical Office (HCSO) and the Research Institute of Agricultural Economics (e.g. Béládi and Kertész, 2008; Keszthelyi and Pesti, 2010) deal only with companies and partnerships as well as family farms (Kovács et al., 2007) or only the cumulative data of companies and partnerships are published and analyzed (Lámfalusi, 2007). Within the data concerning companies and partnerships, information on agricultural co-operatives are not distinguished.

Exceptions are Kapronczai (2010b), two studies by Dorgai (Dorgai, 2004; 2010) and Merkel (2008), in which information on agricultural co-operatives are available.

Today, one cannot find up-to-date information about functioning agricultural co-operatives, which may be caused by political and professional unconcern. As far as I am concerned, we have to consider and utilize lessons in connection with the process of producer co-operatives' decline, since they played a significant role in the agriculture at the time of the change of the regime, as well as regarding the development of so-called new type agricultural co-operatives.

\section{Database and methods}

The fundamental database of my study is based on the publication titled "Main data on farming of companies in agriculture and food industry using double-entry bookkeeping (2002-2007)" by RIAE (Székelyné, 2009). This study, in which one can read about the agricultural and food industrial companies' financial data at current prices (2002-2007), is available in the library of RIAE and on its web page. The database belongs to National Tax and Customs Administration (NAV). Because of the unfavorable weather in 2003, data about output and income are the average of 2002-2003 which is the basis for the time series analysis.

Regarding the land use of co-operatives, I rely on literature sources (Burgerné, 2010; Dorgai, 2004; Kapronczai, 2010a, Kapronczai and Udovecz, 2009).

I applied descriptive statistics and time series analysis. My results and conclusions are presented by simple statistic means (indices, tables, figures).

\footnotetext{
${ }^{1}$ The author is grateful to the Research Institute of Agricultural Economics (RIAE) for the possibility of using the aggregated database of National Tax and Customs Administration.
} 


\section{Number and resources of companies and partnerships}

Table 1 shows the numbers of agricultural organizations, employed people and value of assets in agricultural companies and partnerships. As regards land, unfortunately, I have only approximate data.

Table 1

The change of the numbers of agricultural organizations, employed persons and value of assets in agricultural companies and partnerships from 2003 to 2007

\begin{tabular}{|l|c|c|c|c|c|c|c|c|}
\hline \multirow{2}{*}{} & \multicolumn{2}{|c|}{ Ltd. } & \multicolumn{2}{c|}{ Joint-stock companies } & \multicolumn{2}{c|}{ Co-operatives } & \multicolumn{2}{c|}{ Other organizations } \\
\cline { 2 - 9 } & $\mathbf{2 0 0 3}$ & $\mathbf{2 0 0 7}$ & $\mathbf{2 0 0 3}$ & $\mathbf{2 0 0 7}$ & $\mathbf{2 0 0 3}$ & $\mathbf{2 0 0 7}$ & $\mathbf{2 0 0 3}$ & $\mathbf{2 0 0 7}$ \\
\hline $\begin{array}{l}\text { Number of } \\
\text { organizations }\end{array}$ & 4934 & 4942 & 279 & 271 & 1245 & 848 & 2943 & 2487 \\
\hline $\begin{array}{l}\text { Number of employed } \\
\text { persons }\end{array}$ & 43448 & 38755 & 29602 & 23153 & 21152 & 10598 & 6012 & 6056 \\
\hline $\begin{array}{l}\text { Value of the assets } \\
\text { (Million HUF) }\end{array}$ & 648159 & 942843 & 340698 & 451331 & 178115 & 145763 & 56465 & 67951 \\
\hline
\end{tabular}

Source: Székelyné, 2009

Table 1 shows that within few years after the EU accession the number of limited liability companies (Ltd.) and joint-stock companies has slightly changed, however, the number of other organizations (mainly unlimited and limited partnerships) has decreased by $15 \%$ while the number of co-operatives declined by $32 \%$ (!).

Within data on co-operatives, the number and share of producer co-operatives decreased to a high degree since the number of new type co-operatives grew significantly in the analyzed period. (One part of producer groups and producer organizations in the vegetables and fruits sector works as co-operatives, but the other proportion works in economic corporation forms. [Barta et al., 2009]) There is no opportunity to compare attributes by two types of co-operatives in this study, but it will be an essential part of my research in the future.

The number of co-operatives declined not just in agriculture. According to Pataki László, the vice-president of MOSZ: “...while 6781 co-operatives with 4.5 million members worked in Hungary in 1990, nowadays just 2444 co-operatives with 1 million members are at work and from 2000 villages co-operatives have already disappeared... co-operatives ceased to exist notably as well in the last years and larger proportion of them was transformed into economic corporations." (H. Gy., 2010). It is an interesting fact that as long as approximately 1300 agricultural co-operatives in 1990 and 1915 were registered by HCSO in 1997 (Szabó, 2001), there were only 1886 agricultural co-operatives in 2000 (Kapronczai, 2003).

The number of employed people and their changing share show different pictures. On Figures 1-2 one can see changing data on employed people in each legal form except in case of other organizations. In the latter case one can find stagnation. In co-operatives the number of employed persons dramatically decreased. Figures 1-2 show the shift of relation among legal forms.

Figures 1-2.: Distribution of employed persons by legal forms in 2003 and 2007
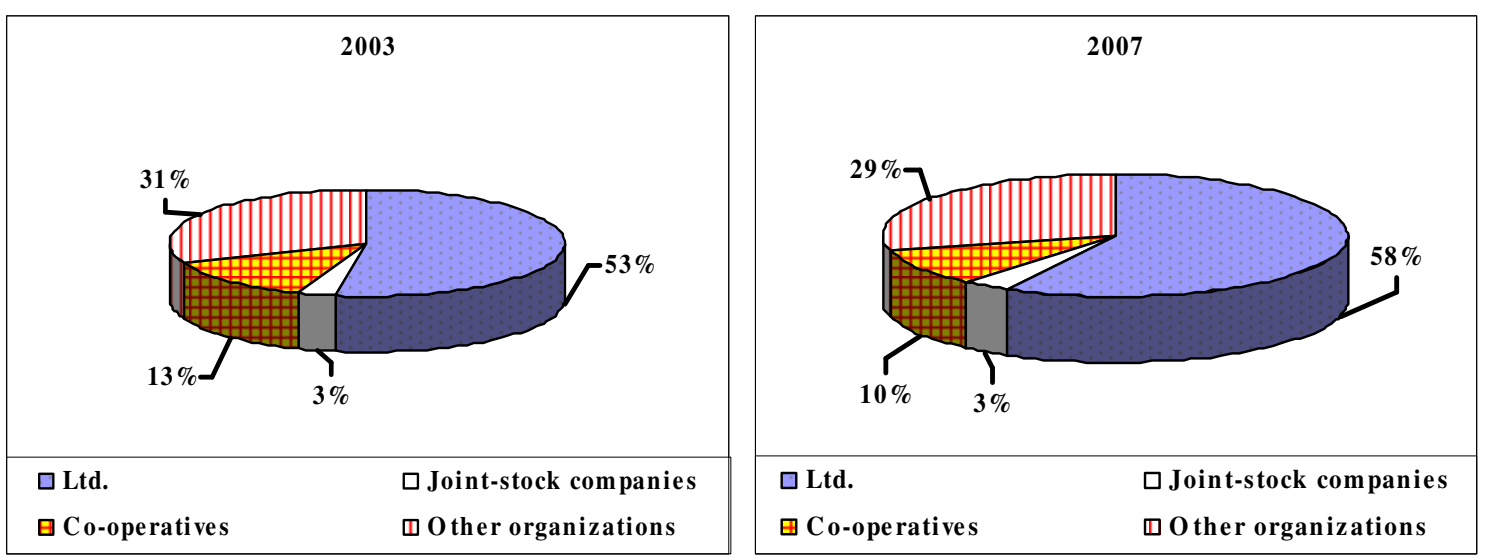

Source: own construction based on Székelyné, 2009 
The change of assets - like above - shows the setback of co-operatives: the value of assets at current price decreased by $20 \%$ while in case of other legal forms it increased by $20-45 \%$. Figures $3-4$ represent the shift of shares of assets among different legal forms.

Figures 3-4.: Distribution of assets by legal forms in 2003 and 2007
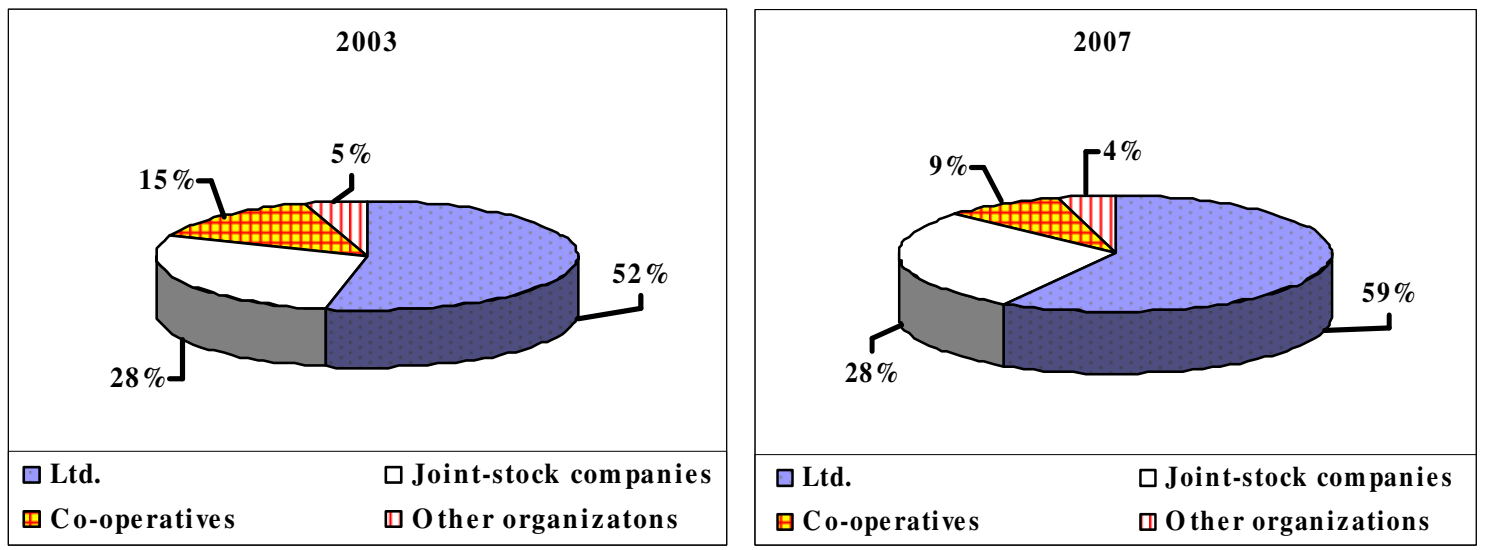

Source: own construction based on Székelyné, 2009

Apart from the obvious dominance by limited liability companies (59\%), one can see in Figures 3-4 that cooperatives had only $9 \%$ of assets in 2007 . At the same time, it is an important conclusion that the value of assets per co-operative and per capita in them increased significantly. Unfortunately, it can not be said that this is due to the changing co-operative structure (producer co-operatives versus the so-termed new type co-operatives) or to the secession of co-operatives which are not viable.

I do not have recent data on land use of agricultural enterprises. It is rare that, within the category of enterprises, separated data on co-operatives are available. According to the reliable data, in 2003 co-operatives have $7 \%$ of total productive land area in Hungary while in 2008 this ratio decreased to $5 \%$ (Kapronczai and Udovecz, 2009).

\section{Analysis of the gross output}

I compared average data for 2-2 years (2002-2003 and 2006-2007) in order to dim the annual affects of weather changing.

In the database, data on gross output and gross value added are attainable as well. Regarding the examined types of organizations, the share of gross value added in gross output remained almost the same: 26-27\%. Table 2 shows the development of gross output and gross value added (average of years of 2002-2003 and 2006-2007).

Development of gross output and gross value added by legal forms between 2002-2003 and 2006-2007 (Million HUF)

\begin{tabular}{|l|c|c|c|c|}
\hline \multirow{2}{*}{} & \multicolumn{2}{|c|}{ 2002-2003 } & \multicolumn{2}{c|}{ 2006-2007 } \\
\cline { 2 - 5 } & Gross output & Gross value added & Gross output & Gross value added \\
\hline Ltd. & 407968 & 97007 & 516642 & 124097 \\
\hline Joint-stock companies & 230248 & 71799 & 246667 & 80097 \\
\hline Co-operatives & 121013 & 36373 & 87244 & 78376 \\
\hline Other organizations & 24358 & 4835 & 38131 & 237416 \\
\hline Total & 783587 & 210015 & 888684 & \\
\hline
\end{tabular}

Source: own collaboration based on Székelyné, 2009

In the analyzed period, agricultural organizations' gross output (at current price) increased by $13.4 \%$ but different organizations' results altered in different manner. It can be seen in Table 2 that the gross output increased slightly in joint-stock companies, increased to a high degree in Ltd. and in case of other organizations, however it decreased by $30 \%$ in co-operatives.

As a next step, I examine the roles of legal forms in gross output. 
Figures 5-6.: Distribution of gross output by legal forms in 2002-2003 and 2006-2007
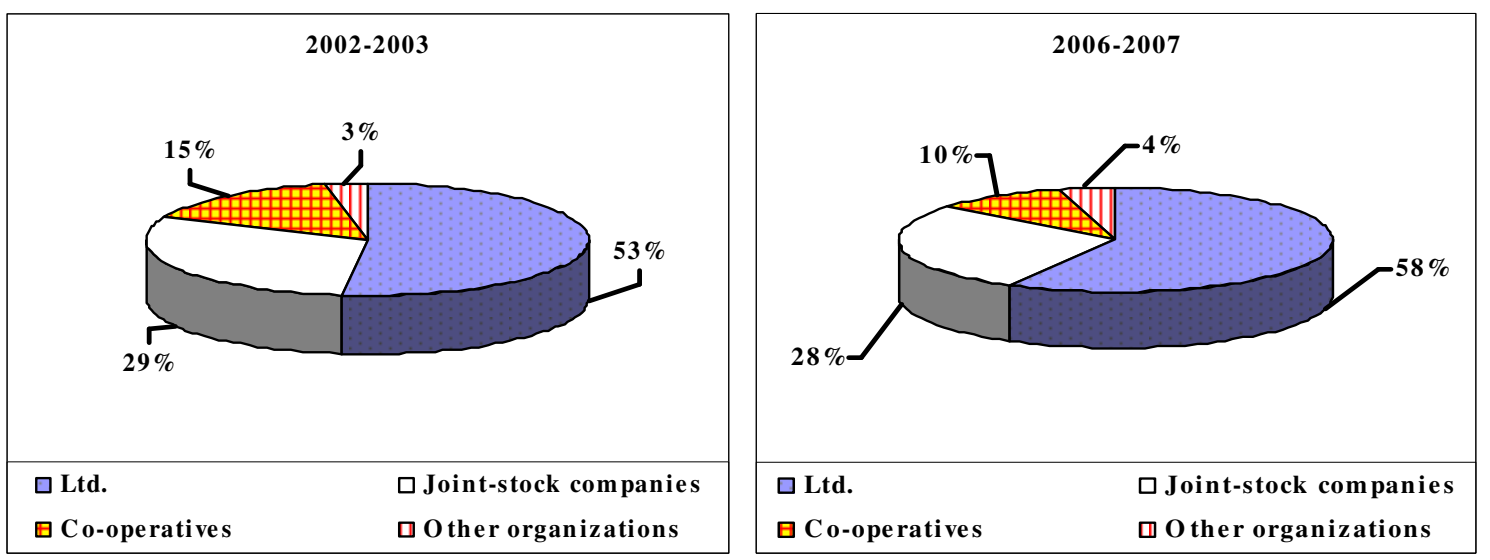

Source: own collaboration based on Székelyné, 2009

According to Figures 5-6 it can be said that enterprises' remarkable part of gross output belongs to Ltd., which extended their participation, while co-operatives' slim share decreased even more.

Results of analysis concerning gross value added are in alignment with conclusions on gross output data.

\section{Conclusions}

In the analyzed period, agricultural organizations were able to show increasing outputs. However the socioeconomic weight of the agricultural co-operatives (land, employment, assets, gross output, and gross added value) has decreased dramatically after EU accession.

In my opinion, an analysis should be done with special regard to characteristics of the producer and the sotermed new type co-operatives in the near future.

\section{REFERENCE}

Barta I.-Dorgai L. (szerk.)-Dudás Gy.-Varga E. (2010): Termelői csoportok és a zöldség-gyümölcs ágazatban müködő termelöi szerveződések Magyarországon. Agrárgazdasági Információk. 2010. 6. sz. AKI, Budapest

Béládi K.-Kertész R. (2008): A föbb mezőgazdasági ágazatok költség- és jövedelemhelyzete a tesztüzemek adatai alapján 2007-ben. Agrárgazdasági Információk. 2008. 6. sz. AKI, Budapest

Burgerné Gimes A. (2010): Még egyszer a földtulajdonról. Gazdálkodás, 54. évf. 5. sz. 548-560.

Dorgai L. (szerk., 2004): A magyarországi birtokstruktúra, a birtokrendezési stratégia megalapozása. Agrárgazdasági Tanulmányok, 2004. 6. sz. AKI, Budapest

H. Gy. (2010): Nemzetközi Szövetkezeti Nap. Magyar Mezőgazdaság. 2010. július 14. 12.

Kapronczai I. (szerk., 2003): A magyar agrárgazdaság a rendszerváltástól az Európai Unióig. Szaktudás Kiadó, Budapest

Kapronczai I.-Udovecz G. (2009): A magyar agrárgazdaság helyzete. Gazdálkodás, 53. évf. 6. sz. 523-545.

Kapronczai I. (2010a): A földbirtok-politika választ igénylö kérdései. Gazdálkodás, 54. évf. 2. sz. 191-201.

Kapronczai I. (2010b): A magyar agrárgazdaság az adatok tükrében az EU-csatlakozás után. Agrárgazdasági Információk. 2010. 12. sz. AKI, Budapest

Keszthelyi Sz.-Pesti Cs. (2010): A tesztüzemi információs rendszer 2009. évi eredményei. Agrárgazdasági Információk.. 2010. 8. sz. AKI, Budapest

Kovács G.-Kovács H.-Lámfalusi I. (2007): A mezőgazdasági vállalkozások pénzgazdálkodásának változó feltételei. Agrárgazdasági Információk. 2007. 4. sz. AKI, Budapest

Lámfalusi I. (2007): Az élelmiszertermelés gazdálkodó szervezeteinek pénzügyi helyzete-2006. Agrárgazdasági Információk. 2007. 8. sz. AKI, Budapest

Merkel K. (2008): Az élelmiszertermelés és az élelmiszerkereskedelem gazdálkodó szervezeteinek pénzügyi helyzete-2007 (Kézirat). AKI, Budapest

Szabó G. (2001): Élelmiszer-gazdaságtan (egyetemi jegyzet). DE ATC AVI - KE ÁTK, Debrecen

Székelyné Raál É. (2009): A kettős könyvvitelt vezető mezőgazdasági és élelmiszeripari szerveztek gazdálkodásának főbb adatai (20022007) (sokszorosított anyag). AKI, Budapest 